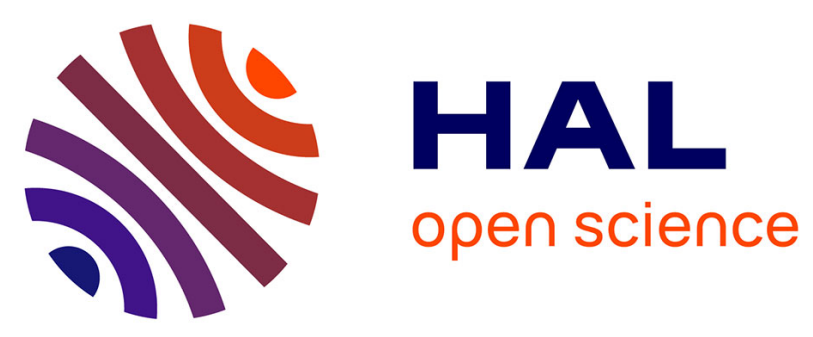

\title{
Description of a very dense meteorite collection area in western Atacama: Insight into the long-term composition of the meteorite flux to Earth
}

Aurore Hutzler, Jérôme Gattacceca, Pierre Rochette, Regis Braucher, Bertrand Carro, Eric J Christensen, Cécile Cournede, Matthieu Gounelle, Nejia Laridhi Ouazaa, Rodrigo Martinez, et al.

\section{To cite this version:}

Aurore Hutzler, Jérôme Gattacceca, Pierre Rochette, Regis Braucher, Bertrand Carro, et al.. Description of a very dense meteorite collection area in western Atacama: Insight into the long-term composition of the meteorite flux to Earth. Meteoritics and Planetary Science, 2016, 51, pp.468 - 482. 10.1111/maps.12607 . hal-01420768

\section{HAL Id: hal-01420768 \\ https://hal-amu.archives-ouvertes.fr/hal-01420768}

Submitted on 21 Dec 2016

HAL is a multi-disciplinary open access archive for the deposit and dissemination of scientific research documents, whether they are published or not. The documents may come from teaching and research institutions in France or abroad, or from public or private research centers.
L'archive ouverte pluridisciplinaire HAL, est destinée au dépôt et à la diffusion de documents scientifiques de niveau recherche, publiés ou non, émanant des établissements d'enseignement et de recherche français ou étrangers, des laboratoires publics ou privés. 


\title{
Description of a very dense meteorite collection area in western Atacama: Insight into the long-term composition of the meteorite flux to Earth
}

\author{
Aurore HUTZLER ${ }^{1 *}$, Jérôme GATTACCECA ${ }^{1,2}$, Pierre ROCHETTE ${ }^{1}$, Régis BRAUCHER ${ }^{1}$, \\ Bertrand CARRO ${ }^{1,3}$, Eric J. CHRISTENSEN ${ }^{4}$, Cécile COURNEDE ${ }^{1}$, Matthieu GOUNELLE 5 , \\ Nejia LARIDHI OUAZAA ${ }^{6}$, Rodrigo MARTINEZ ${ }^{7}$, Millarca VALENZUELA $^{8}$, Michael WARNER $^{9}$ \\ and Didier BOURLES ${ }^{1}$ \\ ${ }^{1}$ Aix-Marseille Université, CNRS, CEREGE UM34, Technopôle de l'Environnement Arbois-Méditerranée, BP80, 13545 \\ Aix-en-Provence, France \\ ${ }^{2}$ Department of Earth, Atmospheric, and Planetary Sciences, Massachusetts Institute of Technology, 77 Massachusetts Avenue, \\ Cambridge, Massachusetts 02139, USA \\ ${ }^{3}$ Ecole Normale Supérieure de Lyon, Lyon 69007, France \\ ${ }^{4}$ Lunar and Planetary Laboratory, University of Arizona, Tucson, Arizona 85721, USA \\ ${ }^{5}$ Institut de minéralogie, de physique des matériaux et de cosmochimie-UMR7590, Muséum National d'Histoire Naturelle, \\ 57 rue Cuvier, 75231 Paris, France \\ ${ }^{6}$ Université de Tunis El Manar, Faculté des Sciences, Unité de Recherche, Pétrologie Cristalline et Sédimentaire, Département de \\ Géologie, Campus Universitaire, 2092 Manar II, Tunis 2092, Tunisia \\ ${ }^{7}$ Museo del Meteorito, San Pedro de Atacama 1410000, Chile \\ ${ }^{8}$ Instituto de Astrofísica, Pontificia Universidad Católica de Chile, Vicuña Mackenna 4860, Macul, Santiago 7820436, Chile \\ ${ }^{9}$ CTIO-NOAO, La Serena 17, Chile \\ *Corresponding author. E-mail: aurore.hutzler@ens-lyon.org
}

(Received 15 August 2014; revision accepted 29 November 2015)

\begin{abstract}
We describe the geological, morphological, and climatic settings of two new meteorite collections from Atacama (Chile). The "El Médano collection" was recovered by systematic on-foot search in El Médano and Caleta el Cobre dense collection areas and is composed of 213 meteorites before pairing, 142 after pairing. The "private collection" has been recovered by car by three private hunters and consists of 213 meteorites. Similar to other hot desert finds, and contrary to the falls and Antarctica finds, both collections show an overabundance of $\mathrm{H}$ chondrites. A recovery density can be calculated only for the El Médano collection and gives 251 and 168 meteorites larger than $10 \mathrm{~g} \mathrm{~km}^{-2}$, before and after pairing, respectively. It is by far the densest collection area described in hot deserts. The Atacama Desert is known to have been hyperarid for a long period of time and, based on cosmic-ray exposure ages on the order of 1-10 Ma, to have been stable over a period of time of several million years. Such a high meteorite concentration might be explained invoking either a yet unclear concentration mechanism (possibly related to downslope creeping) or a previously underestimated meteorite flux in previous studies or an average terrestrial age over 2 Myr. This last hypothesis is supported by the high weathering grade of meteorites and by the common terrestrial fragmentation (with fragments scattered over a few meters) of recovered meteorites.
\end{abstract}

\section{INTRODUCTION}

Deserts experience semiarid to hyperarid climates which allow preservation and accumulation of meteorites. In hot deserts, the lack of vegetation and the favorable geomorphologic features simplify the search for meteorites. They are easier to reach than Antarctica, where the surfaces with the highest meteorite density 
have been found so far, with more than 30 meteorites per $\mathrm{km}^{2}$ in some areas (Huss 1990). Twenty-eight percent of the meteorites in collections comes from hot deserts, compared with 67\% from Antarctica (after Meteoritical Bulletin Database).

The Atacama Desert is the oldest continuously arid region on Earth (Clarke 2006). For at least the last 25 $\mathrm{Ma}$, it has been affected by very low denudation rates (Dunai et al. 2005). Compared with the thoroughly searched deserts of Sahara, Arabia (mostly Oman), the southwest United States (SW USA), and Australia, relatively few meteorites have been recovered in the Atacama Desert so far (see review of Munoz et al. 2007). However, as shown in Gattacceca et al. (2011), it is a very promising place for meteorite recovery, with locally high meteorite concentrations, estimated for instance to 14 unpaired meteorites per $\mathrm{km}^{2}$ in the San Juan dense collection area (DCA). This density is at least one order of magnitude larger than the one estimated in Oman or Libya, for example (Schlüter et al. 2002; Al-Kathiri et al. 2005; Hezel et al. 2011). In fact, as for meteorite recovery rate, Atacama recently ranked among the major deserts apart from the Sahara from which most meteorites are usually collected without geographic information, at the same level as Oman and an order of magnitude over Australia and SW USA (Fig. 1). Only 40 meteorites have been found in Chile before 1986 when an extensive dedicated search started. These finds were made occasionally by geologists and mining prospectors, who concentrated on iron meteorites (34 over a total of 40 finds). Since 1986, several hundreds of meteorites have been recovered, mostly in dense collection areas.

In this article, we present the outcomes of recent meteorite recovery expeditions to Caleta El Cobre and El Médano DCAs in the Atacama Desert. This collection accounts for 213 meteorites. We also present the analysis of another collection of 213 Chilean meteorites collected in Los Vientos, Catalina, Paposo, El Médano, and San Juan DCAs mostly by three independent private meteorite hunters. All these meteorites have been collected and classified specifically for this study. These seven DCAs concentrate most meteorite finds in Chile since 1986 (426 of 655 meteorites). We compare these collections to another well-documented Chilean collection from the San Juan DCA (Gattacceca et al. 2011). Pampa de Mejillones and La Yesera DCAs account for 21 meteorites, but they are not presented here because of their different climatic settings.

After describing the methods used to classify the meteorites, to study surface ages, and to identify paired meteorites, we describe the geology, geomorphology, and climate of the area. Meteorite collections are then

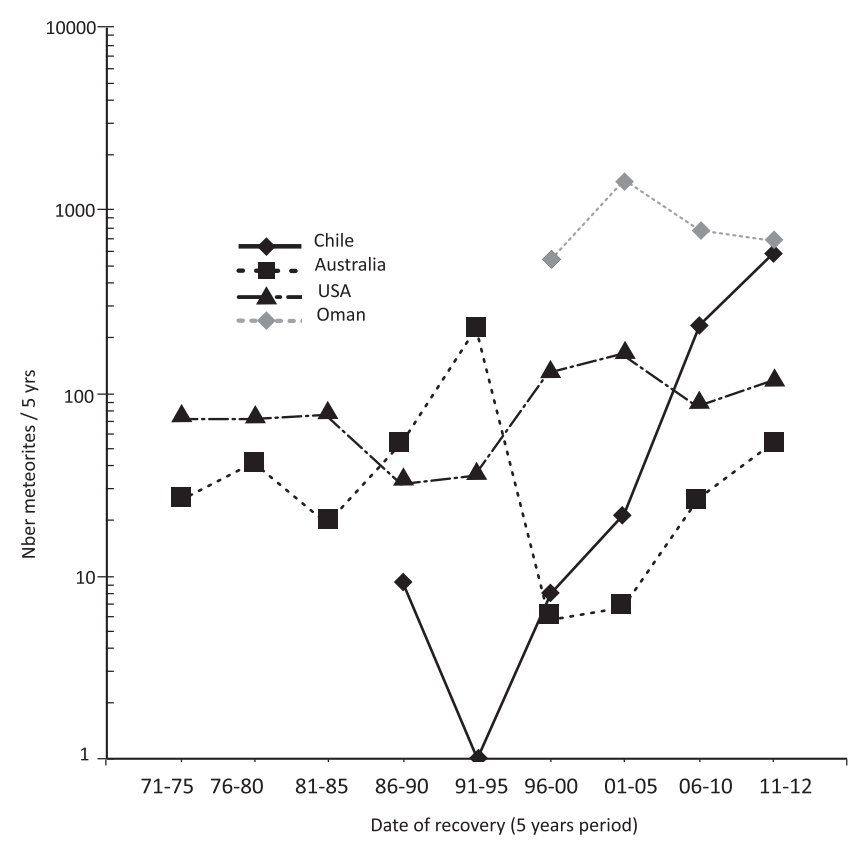

Fig. 1. Number of meteorites recovered per period of 5 years in various deserts: since 1971 in Australia and SW USA, 1986 in Chile, and 1996 in Oman. For the last period only the 2011-2012 years are counted (and adjusted to a 5-year period by multiplying by 2.5). From the Meteoritical Bulletin database as of April 2014.

described in detail, and the statistics of both collections are presented and discussed. Meteorite concentration results from the El Médano collection are finally presented and linked to the flux of meteorites to the Earth.

\section{METHODS}

\section{Meteorite Classification}

Classification was performed at CEREGE. Petrologic type (Van Schmus and Wood 1967) and weathering grade (Wlotzka 1993) were determined on polished sections using a Leica DM polarizing microscope. Petrographic observations were realized independently by two of the authors (J. Gattacecca, A. Hutzler) to ensure maximum reliability. Electron microprobe analyses were performed at Camparis facility (Université Paris 6), using a Cameca SX100 or a Cameca SX Five, and at the MIT microprobe facility (Cambridge, Massachusetts) using a JEOL-JXA-8200 microprobe using natural standards. SEM imaging was performed on a Hitachi S-3000N microscope at CEREGE. Magnetic susceptibility was measured at CEREGE using a KLY2 instrument from Agico. Measurements were taken along three orthogonal axes to minimize anisotropy effects. For samples too large to fit inside the $65 \mathrm{~cm}^{3}$ KLY2 coil, a SM30 contact probe was used using the calibration of Gattacceca et al. (2004). 
Table 1. Exposure ages for five quartz pebbles collected in Caleta el Cobre and El Médano DCAs. Samples were about $5 \mathrm{~cm}$ thick. A density of $2500 \mathrm{~kg} \mathrm{~m}^{3}$ was used. Topographic shielding factor was 1 .

\begin{tabular}{llllll}
\hline $\begin{array}{l}\text { Sample } \\
\text { name }\end{array}$ & $\begin{array}{l}\text { Altitude } \\
(\mathrm{m})\end{array}$ & Latitude/longitude & $\begin{array}{l}\begin{array}{l}\left.{ }^{10} \mathrm{Be}\right] \\
(\text { Matoms.g }\end{array} \\
\hline \text { Q1 }\end{array}$ I $\left.^{-1}\right)$ & $\begin{array}{l}\text { Minimum exposure } \\
\text { age }(\mathrm{Ma})\end{array}$ & $\begin{array}{l}\text { Max. erosion } \\
\text { rate }\left(\mathrm{cm} \mathrm{Ma}^{-1}\right)\end{array}$ \\
Q2 & 2082 & $-24.429050^{\circ} ;-70.308110^{\circ}$ & $23.84 \pm 0.55$ & $4.15 \pm 0.1$ & 2.8 \\
Q3 & 2305 & $-24.737374^{\circ} ;-70.363476^{\circ}$ & $16.31 \pm 0.41$ & $1.59 \pm 0.04$ & 2.7 \\
Q4a & 2089 & $-24.639760^{\circ} ;-70.285610^{\circ}$ & $37.89 \pm 1.1$ & Impossible & 2.8 \\
Q4b & 2076 & $-24.652550^{\circ} ;-70.343340^{\circ}$ & $29.46 \pm 0.69$ & Impossible & 2.8 \\
\hline
\end{tabular}

\section{Surface Ages}

To estimate the surface ages, we measured the concentrations of cosmogenic ${ }^{10} \mathrm{Be}$ produced in situ within quartz pebbles collected at the surface of the desert. Samples were fragments of massive quartz veins that are found occasionally on the surface of the desert.

Sample preparation followed the procedure described in Brown et al. (1991) and Merchel and Herpers (1999). Pure quartz was obtained by repeated $\mathrm{H}_{2} \mathrm{SiF}_{6}-\mathrm{HCl}$ etching. Atmospheric ${ }^{10} \mathrm{Be}$ was subsequently eliminated by sequential dissolutions with diluted HF; $\sim 100 \mu \mathrm{l}$ of an in-house $3 \times 10^{-3} \mathrm{~g} \mathrm{~g}^{-1}{ }^{9} \mathrm{Be}$ carrier solution, prepared from deep-mined phenakite (Merchel et al. 2008), was added to each sample, and residual grains were dissolved in a strong HF solution. After the obtained solutions were evaporated to dryness and the residues were dissolved in hydrochloric acid, beryllium was separated by anion and cation exchange columns. After reduction of the solution volumes by heating, the beryllium hydroxides precipitated using $\mathrm{NH}_{3 \text { aq }}$ were dried and finally ignited at $900{ }^{\circ} \mathrm{C}$ to $\mathrm{BeO}$. $\mathrm{BeO}$ targets were prepared for measurement at the French National Accelerator Mass Spectrometry facility (ASTER), in CEREGE, Aix-en-Provence. The obtained ${ }^{10} \mathrm{Be} /{ }^{9} \mathrm{Be}$ ratios were corrected for procedural blanks and calibrated against the National Institute of Standards and Technology standard reference material 4325 by using an assigned value of $2.79 \pm 0.03 \times 10^{-11}$ and a ${ }^{10} \mathrm{Be}$ half-life of $1.387 \pm 0.012 \times 10^{6}$ years (Chmeleff et al. 2010; Korschinek et al. 2010). Analytical uncertainties (reported as $1 \sigma$ ) include uncertainties associated with AMS counting statistics, chemical blank measurements, and AMS internal error $(0.5 \%)$. Longterm AMS measurements of procedural blanks yield a background ratio of $3.0 \pm 1.5 \times 10^{-15}$ for ${ }^{10} \mathrm{Be} /{ }^{9} \mathrm{Be}$ (Arnold et al. 2010). A sea level, high-latitude (SLHL) spallation production of 4.49 at $\mathrm{g}^{-1} \mathrm{yr}^{-1}$ was used and scaled for latitude and elevation (Stone 2000). All obtained ${ }^{10} \mathrm{Be}$ data are reported in Table 1.

Minimum exposure age has been calculated assuming no denudation, and maximum denudation rate has been calculated assuming an infinite exposure age.

\section{GEOLOGY AND GEOMORPHOLOGY}

The Atacama Desert is located between the western central Andes and the Pacific Ocean. It extends from Southern Peru $\left(18^{\circ} \mathrm{S}\right)$ to Copiapo, Chile $\left(30^{\circ} \mathrm{S}\right)$. The two contiguous DCAs we have investigated, El Médano and Caleta el Cobre, are located between $24^{\circ} \mathrm{S}$ and $26^{\circ} \mathrm{S}$ latitude and centered on $70^{\circ} \mathrm{W}$ longitude (Fig. 2). They overlap two morphotectonic units: the Coastal Range and the Central Depression. The Coastal Range is influenced by a coastal fog and thus is only semiarid, whereas the Central Depression is hyperarid, being protected from the coastal fog influences by the western margin $(<1000 \mathrm{~m})$ and from the seasonal rainfall in the Andes ( $>2800 \mathrm{~m})$ (Munoz et al. 2007). The search concentrated only on the hyperarid part of these DCAs, that is, the Central Depression. El Médano and Caleta el Cobre productive search areas are bordered to the west by the Atacama Fault (Fig. 2). El Médano and Caleta el Cobre DCAs are composed of two main geological formations: Jurassic-Cretaceous intrusive igneous rocks (granodiorites, diorites, and gabbros) and Mio-Pliocene alluvium and colluvium.

The investigated area is a set of approximately 30 small areas (Fig. 2), for a total of $1.5 \mathrm{~km}^{2}$ that were searched systematically on foot. They spread over a total surface of approximately $200 \mathrm{~km}^{2}$, ensuring a smaller probability of pairing with respect to a single rectangle of $1.5 \mathrm{~km}^{2}$. El Médano and Caleta el Cobre DCAs are different from San Juan DCA in that the favorable places for meteorite search are less extended because of more pronounced topography. Relatively flat surfaces, in an altitude range from $1950 \mathrm{~m}$ to $2400 \mathrm{~m}$ a.s.l (above sea level), were searched. The vast majority of the investigated surfaces present a gentle average slope below $3^{\circ}$ (at a few hundred meters scale). Surfaces with a slope higher than $6^{\circ}$ were not investigated, as meteorites may not be stable in the long term on such slopes.

The other DCAs included in this study, Paposo, Los Vientos, Catalina, and San Juan were searched in a 


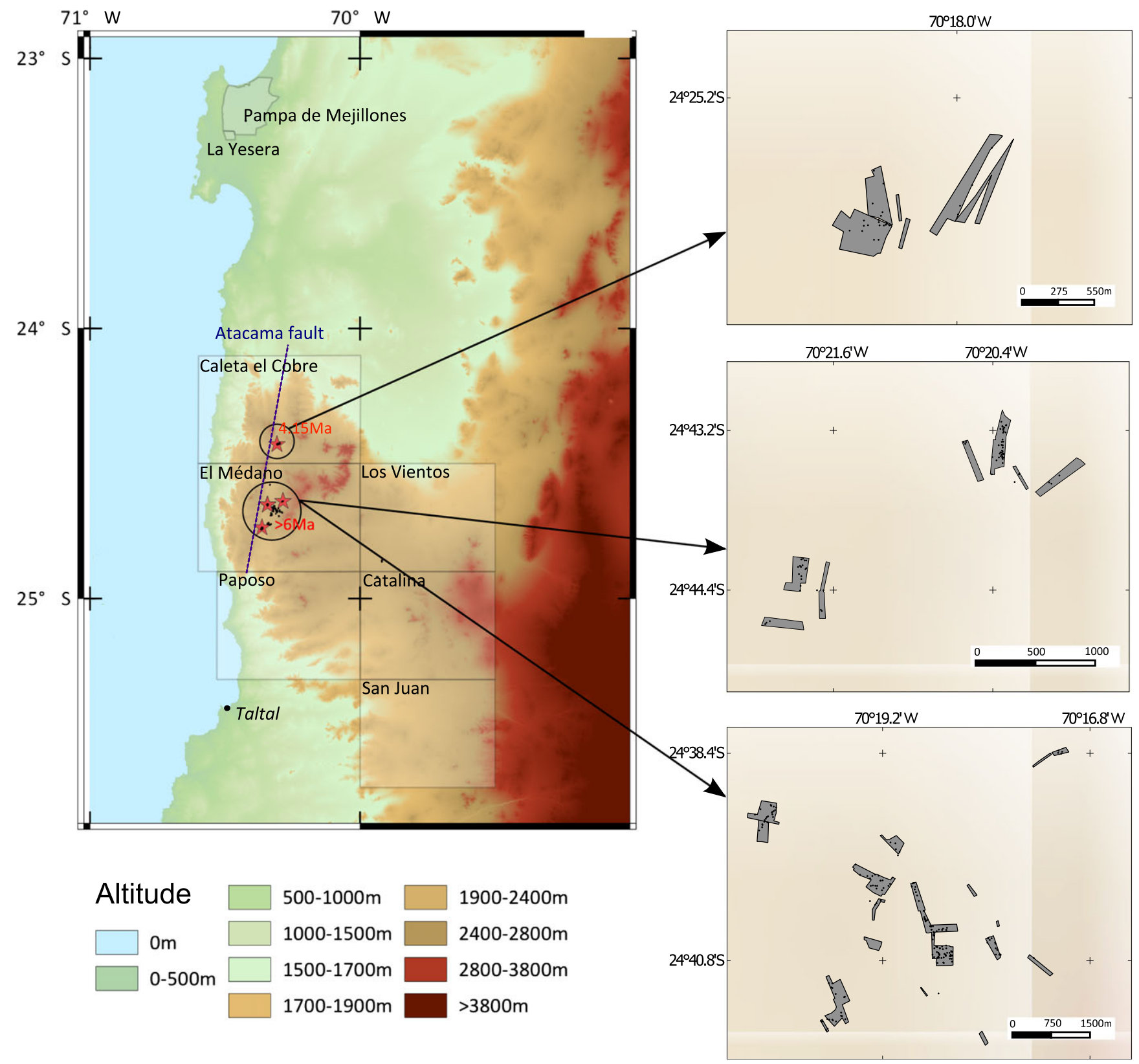

Fig. 2. Map of Chilean DCAs and explored areas in the Caleta el Cobre DCA and the El Médano DCA. Dated quartzes are represented by red stars. Meteorites are represented by black dots. The Atacama fault is indicated on the main map. The data were obtained through the online Data Pool at the NASA Land Processes Distributed Active Archive Center (LP DAAC). ASTER GDEM is a product of METI and NASA.

nonsystematic manner and mostly by car by three of the authors (R. Martinez, E.J. Christensen, M. Warner). They also searched in El Médano (18 meteorites recovered). While the Paposo search zone is the southern prolongation of El Médano, the Los Vientos and Catalina search areas are located farther East in the central depression, north of the San Juan DCA (Fig. 2).

Surface ages estimated from the cosmic-ray exposure (CRE) ages of surface quartz pebbles are given in Table 1 . The ${ }^{10} \mathrm{Be}$ is produced in situ by cosmics rays and accumulates within oxygen-rich rock minerals, mainly quartz, while they are exposed to energetic cosmic-ray-derived particles at or close to the Earth's surface. Its concentration depends on the geomorphological stability of the sampled surfaces. Indeed, it results from both the gain accumulated during the exposure duration within the first meters of Earth surface and from losses due to radioactive decay 
Table 2. Difference between current altitude and required altitude for three different exposure ages for quartz pebbles (Table 1$)(\Delta=$ required altitude-current altitude).

\begin{tabular}{lllll}
\hline & $\begin{array}{l}\text { Sample } \\
\text { Sample }\end{array}$ & $\begin{array}{l}\Delta \text { if } \\
\text { altitude }\end{array}$ & $\begin{array}{l}\mathrm{T}_{\text {age }}=1.8 \\
\text { if }\end{array}$ & $\begin{array}{l}\Delta \text { if } \\
\text { age }\end{array}$ \\
name & $(\mathrm{m})$ & Ma $(\mathrm{m})$ & $\begin{array}{l}\text { Ma }(\mathrm{m}) \\
\text { age }\end{array}$ & Ma $(\mathrm{m})$ \\
\hline Q3 & 2305 & +969 & +339 & +187 \\
Q4a & 2089 & +759 & +154 & +8 \\
Q4b & 2076 & +783 & +153 & +31 \\
\hline
\end{tabular}

and to the denudation (both chemical weathering and physical erosion) affecting the sampled surface. By measuring only one cosmogenic nuclide concentration, it is not possible to determine both exposure duration and denudation rate. We may determine either a minimum exposure duration assuming no denudation or a maximum denudation rate assuming an infinite exposure duration. Because denudation rates may be considered negligible in the Atacama Desert $\left(<3 \mathrm{~cm} \cdot \mathrm{Ma}^{-1}\right.$, Dunai et al. 2005), minimum exposure durations were estimated.

However, the in situ-produced ${ }^{10} \mathrm{Be}$ concentration measured in three pebbles out of five is out of the theoretical maximum ${ }^{10} \mathrm{Be}$ range, that is, even an infinite exposure duration with no denudation cannot account for the measured ${ }^{10} \mathrm{Be}$. The only probable explanation for such an observation is that these samples have accumulated their ${ }^{10} \mathrm{Be}$ concentration at a higher altitude and have then crept down the slope to reach the current sampling altitude. In Table 2, the altitudes where the quartz pebbles should have been exposed were calculated for three arbitrary-chosen exposure durations (1.8 Ma, $4 \mathrm{Ma}$, and $>6 \mathrm{Ma}$ ). Considering the altitudes of the surroundings, and the local morphologies, we can evaluate if such an altitude change is reasonable. Q4a and $\mathrm{Q} 4 \mathrm{~b}$ are at the bottom of circa $200 \mathrm{~m}$ high hills, with an average slope of $5.8^{\circ}$. Hence, it is likely that quartz pebbles have crept down the hills to account for the limited altitude difference needed to fit the data with an exposure duration $>4 \mathrm{Ma}$. As for Q3, it lies on a surface with a gentle slope of $3.7^{\circ}$ with no high hills in the vicinity (in a radius of $2 \mathrm{~km}$, maximum altitude is $2430 \mathrm{~m}$ a.s.1.). Hence, it cannot have come from a too high altitude, and a long exposure duration is very likely.

Even accounting for the uncertainty of a change of altitude, it is clear that our quartz samples studied were exposed for more than $1.5 \mathrm{Ma}$ and up to $>6 \mathrm{Ma}$. Therefore, the El Médano and Caleta el Cobre DCAs have older surface exposure ages than the San Juan DCA (where exposure durations determined with the same methodology yield consistent minimum exposure durations of $1.5 \mathrm{Ma}$ ). A more detailed study of exposure history, including noble gases data, will be performed in the future.

\section{CHARACTERISTICS OF STUDIED COLLECTIONS}

We present here two distinct Chilean meteorite collections.

The first collection was recovered during two search campaigns organized by CEREGE and the University of Chile in 2010 and 2011. The search was conducted by foot alongside a grid of parallel lines, $10 \mathrm{~m}$ distant from each other. The investigated areas are spread across the El Médano DCA and the Caleta el Cobre DCA (Fig. 2). Since all the investigated areas are part of the same geomorphological unit, all results are presented together and this collection will be referred to in the rest of the text as the "El Médano collection" or the "EM collection."

Two hundred eighty-one meteorites were recovered over a cumulated surface of $1.5 \mathrm{~km}^{2}$ (Caleta el Cobre 001-021, and El Médano 001-152; 158-169; 179-192; $195-200 ; 202-210)$. Thirty-one percent of the meteorites were fragmented and scattered over a few meters. In every case where multiple fragments were recovered, a systematic study was conducted through visual inspection and measurement of magnetic susceptibility to check these were indeed fragments of the same meteorite. In some cases, this led to the identification of two different meteorites whose fragments were mixed over an area of only a few tens square meter. Meteorites with a mass lower than $10 \mathrm{~g}$ were not studied, except for the ones that seemed unusual (22 stones), since we noticed a sharp break in the cumulative plot of number of meteorites versus mass below $10 \mathrm{~g}$ indicating a lower collection efficiency in this size range. This leaves 213 meteorites that were classified and declared to the Meteorite Nomenclature Committee of the Meteoritical Society. Except for the mass distribution which considers all stones found (191 classified meteorites over $10 \mathrm{~g}, 22$ classified meteorites under $10 \mathrm{~g}$, and 68 meteorites under $10 \mathrm{~g}$ that have not been classified but whose magnetic susceptibility and visual examination prove they are meteorites), in the following, only the results regarding the 213 classified meteorites are discussed. Meteorites were mostly of brownish color due to weathering (Fig. 3). About 30\% of the meteorites over $200 \mathrm{~g}$ are still covered by fusion crust on more than half their surface. Meteorites were slightly buried, the burial depth ranging from a few millimeters to $5 \mathrm{~cm}$, the larger stones being more buried in absolute terms. Most meteorites show a whitish deposit of caliche (consisting mostly of anhydrite) on the buried side. 


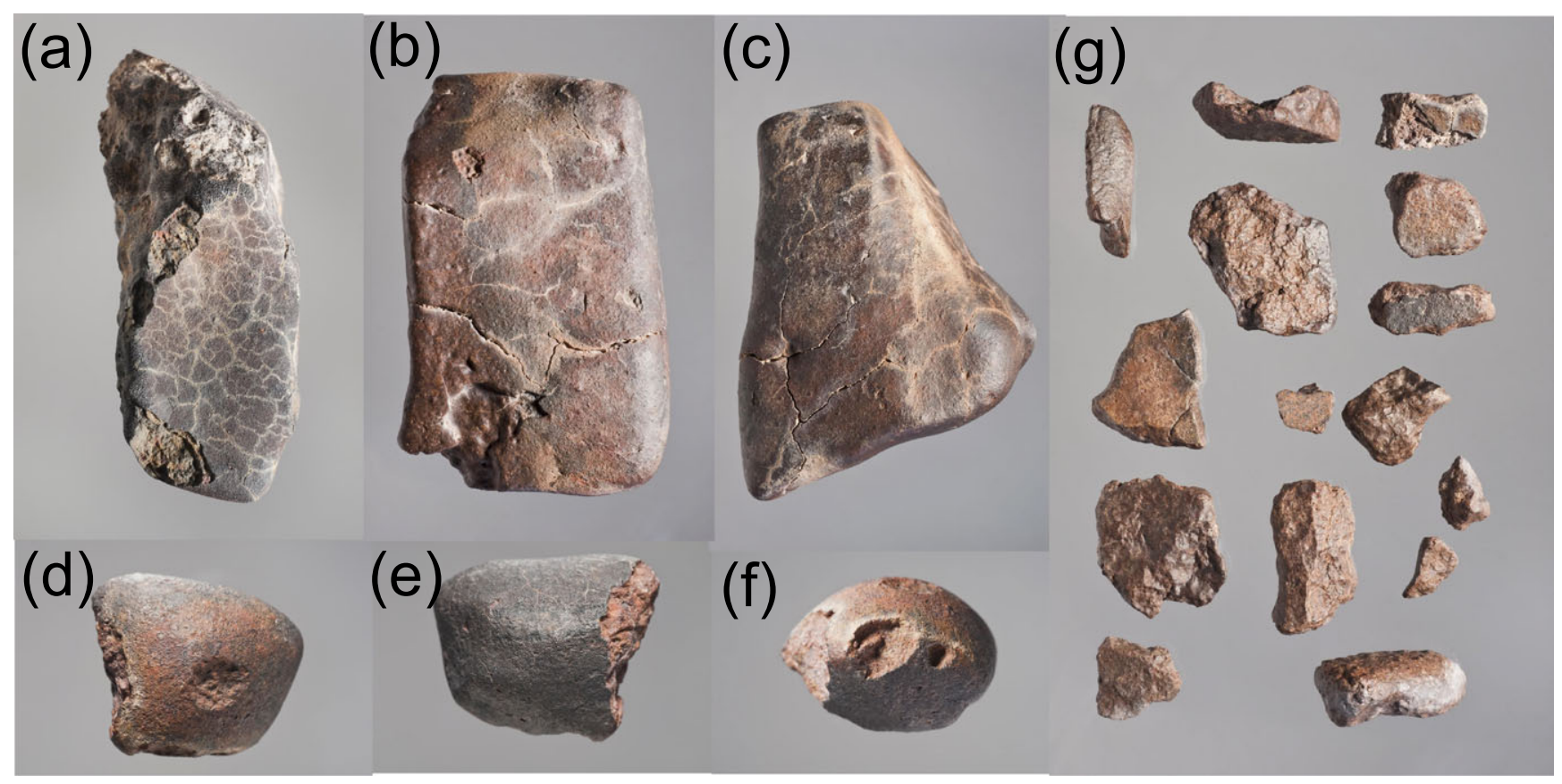

Fig. 3. Photographs of meteorites from the El Médano DCA. a) El Médano 133, an LL6 ordinary chondrite (397 g). b and c) El Médano $078(1228 \mathrm{~g})$. d, e, and f) El Medano $101(19.1 \mathrm{~g}) . \mathrm{g})$ El Médano 185 several pieces of a more typical meteorite from the Atacama (total weight: $172 \mathrm{~g}$ ). Note the brownish color and the rather flat shape of the pieces.

The second collection, called "private collection" here, also amounts to 213 meteorites (Los Vientos 001058; 062; 068-070; 072-073; Catalina 002-004; 008-088; 092-106; Paposo 002-018; El Médano 056; 153-157; 170178; 193; 194; 201; 211-217; San Juan 063-069). It was recovered since 2009 by three of the authors (R. Martinez, E.J. Christensen, M. Warner), searching mostly by car in the central depression. All but four meteorites were classified at CEREGE. Note that the meteorites composing the private collection are only a part of the vast meteorite collections of these hunters. The stones selected for classification may have been sometimes selected based on an unusual feature or unusual magnetic susceptibility, which may have artificially enhanced the abundance of rare meteorites. The meteorites in this collection come from different DCAs: Los Vientos (64 meteorites), Catalina (99 meteorites), El Médano (25 meteorites), Paposo (18 meteorites), and San Juan (7 meteorites). We combine the results for all these areas. Exact locations of finds inside the DCA are temporarily undisclosed since more collecting work is in progress. Since the private collection is not from a systematic search, we did not study the pairing between meteorites. Note that among the 70 San Juan meteorites present in the Meteoritical Society Database, 7 meteorites are part of the private collection, the rest being reported in Gattacceca et al. (2011). The physical aspect of the stones in the private collection is roughly the same as in the EM collection.
Meteorites from both collections were reported in the Meteoritical Bulletins No. 89 (Russel et al. 2005), 100, 101, 102, and 103 (Ruzicka et al. 2014, 2015a, 2015b et al. 2014, 2015a, 2015b).

\section{PAIRING}

Pairing is a crucial step in any study willing to investigate quantitatively abundances of types of meteorites and meteorite concentration. When studying a small collection of meteorites, the easiest and most reliable way to identify paired meteorites is to compare each meteorite with all other meteorites in terms of quantitative characteristics (e.g., mineral composition, physical properties) and qualitative characteristics (texture under the petrographic microscope, overall aspect of the stones). With a collection of 213 potentially paired meteorites, it means comparing over 10,000 duos (if we consider meteorites from different groups cannot be paired). Because this is not doable, we looked for a way to reduce the number of meteorite duos that had to be compared.

Literature about pairing mostly revolves around one seminal study by Benoit et al. (2000). But we had to develop our own approach, for two reasons. First, Benoit et al. used preset abundances from falls to find a pairing probability: this method does not allow us to study the possible variations in the composition of the 
flux of meteorite over time. Second, after computing a pairing probability for each criterion, they calculate the product of these probabilities, whereas they should use the geometric mean: their results are not mathematically homogenous.

When trying to identify paired meteorites, one compares each available quantitative criteria (petrologic type, weathering grade, geographic location, and so on), and as long as the criteria match (within a certain interval, specific for each criteria), the meteorites are considered as potentially paired. If all criteria match, pairing is checked by inspection of the texture. We designed a mathematical model which compares the quantitative criteria and tells us if we should compare their texture under the microscope or if the two meteorites are unrelated.

For each criterion, the model computes a pairing factor " $p$ " indicating the likeliness, according to this criterion, of the two meteorites being paired. Then, the model computes the geometric mean of those factors and validates the pairing if the result is high enoughthe minimal value having been calibrated using preexisting collections that have been paired already (here we used the collection of San Juan DCA, in Gattacceca et al. 2011).

Each pairing factor $p_{i}$ (for the $i$ criterion) is determined via an ad hoc mathematical formula, calibrated with the same meteorite collections. We note $\mathrm{v}_{\mathrm{A}}\left(\right.$ resp. $\mathrm{v}_{\mathrm{B}}$ ) the value of a given criterion of meteorite A (resp. meteorite B).

For fayalite and ferrosillite contents, the formula is a function of the difference $\mathrm{v}_{\mathrm{A}}-\mathrm{v}_{\mathrm{B}}$ between the values of meteorites A and B and is modeled as a Gaussian, since we needed a function giving values close to 1 when $\mathrm{v}_{\mathrm{A}^{-}}$ $\mathrm{v}_{\mathrm{B}}$ was not too far from 0 and quickly decreasing after a given threshold.

Petrologic type adopts discrete values. A discrete function of $\mathrm{v}_{\mathrm{A}}$ and $\mathrm{v}_{\mathrm{B}}$ was consequently chosen (see Table 3), replicating the pairing probabilities between meteorites of different types.

For shock and weathering grades, since values are discrete, $\mathrm{p}$ adopts calibrated values, whether $\mathrm{v}_{\mathrm{A}}-\mathrm{v}_{\mathrm{B}}$ is equal to 0,1 , or more than 1 .

As to geographic position, a piecewise constant function of the distance (Table 4) was used, since we considered this criterion as mostly useful for invalidating pairings of stones distant of more than $50 \mathrm{~km}$. The probability function might be dependent on the area and thus must be adapted to each environment. For example, in the Allan Hills region of Antarctica, paired fragments were only a few kilometers apart (Benoit et al. 1993), whereas in the Elephant Moraine area, fragments were more widely scattered (Benoit et al. 1994).
Table 3. Parameters used in the pairing model for ElM collection.

\begin{tabular}{|c|c|c|c|}
\hline Criterion & Distribution & Parameters & Weight \\
\hline $\begin{array}{l}\text { Weathering } \\
\text { grade }\end{array}$ & Gaussian & 1.3 & 1 \\
\hline Shock grade & Gaussian & 1.3 & 2 \\
\hline $\begin{array}{l}\text { Fayalite } \\
\text { content }\end{array}$ & Gaussian & 0.7 & 2 \\
\hline $\begin{array}{l}\text { Ferrosillite } \\
\text { content }\end{array}$ & Gaussian & 0.7 & 2 \\
\hline $\begin{array}{l}\text { Magnetic } \\
\text { susceptibility }\end{array}$ & Gaussian & 0.7 & 2 \\
\hline $\begin{array}{l}\text { Petrographic } \\
\text { type }\end{array}$ & Discrete & $\begin{array}{l}P=1 \text { if } \Delta=0 \\
P=0.75 \text { if } \Delta=1 \\
P=0.1 \text { if } \Delta>1\end{array}$ & 1 \\
\hline Distance & Discrete & $\begin{array}{l}P=1 \text { if } d<10 \mathrm{~m} \\
P=0.85 \text { if } d<10 \mathrm{~km} \\
P=0.83 \text { if } d<20 \mathrm{~km} \\
P=0.8 \text { if } d<30 \mathrm{~km} \\
P=0.75 \text { if } d<40 \mathrm{~km} \\
P=0.3 \text { if } d<50 \mathrm{~km} \\
P=0 \text { if } d>50 \mathrm{~km}\end{array}$ & 0.5 \\
\hline
\end{tabular}

Since some criteria are more relevant than others, we assigned to each criteria a weight reflecting its robustness (when calculating the geometric mean).

Pairing criteria listed in Benoit et al. (2000) as primary were given a weight of 2: shock grade, magnetic susceptibility, fayalite, and ferrosillite content, except for the weathering grade, which may be variable within a meteorite. Other criteria were given a weight of 1. Distance is usually only supportive of pairing: thus, we used a weight of 0.5 . Also, since the search areas are rather disseminated, distance is not really statistically reliable.

Since a pairing can be invalidated by a single criterion, we chose to calculate pairing probability using geometric mean (based on the product of the values) and not arithmetic mean (based on the sum of the values), which would hide nonconclusive criteria.

The model calculates $P$, a factor transcribing the probability of two meteorites being paired, following the formula:

$$
P=\left(\prod_{i} p_{i}^{w_{i}}\right)^{1 / \sum w_{i}}
$$

with $p_{i}$ the probability of pairing for two meteorites for the $i$ criterion and $w_{i}$ the weight given to the $i$ criterion.

We used this model exclusively for equilibrated ordinary chondrites. Other types of meteorites are rare enough in our collection to evaluate pairing directly, without using a pairing model. 
Table 4. Pairing groups of the El Médano collection.

\begin{tabular}{|c|c|c|c|c|}
\hline Pairing group name $\mathrm{a}^{\mathrm{a}}$ & Paired meteorites & Number of stones & Classification & TKW (g) \\
\hline Caleta El Cobre 002 & CeC 019 & 2 & H6 & 19.1 \\
\hline Caleta El Cobre 003 & СeC 005; CeC 016; СeC 017 & 23 & $\mathrm{H} 5$ & 606 \\
\hline Caleta El Cobre 006 & $\mathrm{CeC} 015$ & 2 & L6 & 294 \\
\hline Caleta El Cobre 009 & CeC 010; СeC 012 & 3 & L4 & 159 \\
\hline El Médano 001 & EM 032; EM 058 & 3 & H6 & 49.8 \\
\hline El Médano 004 & EM 068 & 14 & $\mathrm{H} 4$ & 276 \\
\hline El Médano 005 & EM 128; EM 129 & 7 & L6 & 1165.8 \\
\hline El Médano 006 & EM 007; EM 073 & 3 & LL6 & 153 \\
\hline El Médano 009 & EM 101 & 2 & L6 & 84.1 \\
\hline El Médano 010 & EM 014; EM 059 & 5 & $\mathrm{H} 4$ & 88 \\
\hline El Médano 011 & EM 012 & 3 & H6 & 141 \\
\hline El Médano 015 & EM 018 & 2 & $\mathrm{H} 4$ & 113 \\
\hline El Médano 019 & EM 179 & 2 & $\mathrm{H} 3$ & 25.9 \\
\hline El Médano 021 & EM 022; EM 025; EM 036 & 5 & H6 & 283 \\
\hline El Médano 024 & EM 033; EM 111 & 3 & $\mathrm{H} 5$ & 193 \\
\hline El Médano 027 & EM 035 & 2 & H5 & 118 \\
\hline El Médano 028 & EM 029 & 18 & L5 & 533 \\
\hline El Médano 030 & EM 034 & 3 & H6 & 42 \\
\hline El Médano 038 & EM 116 & 3 & H6 & 49.8 \\
\hline El Médano 043 & EM 084; EM 151 & 5 & $\mathrm{H} 4$ & 82.4 \\
\hline El Médano 044 & EM 141 & 6 & L6 & 796.4 \\
\hline El Médano 045 & EM 065; EM 186 & 6 & $\mathrm{H} 5$ & 549.5 \\
\hline El Médano 049 & EM 087; EM 131 & 9 & $\mathrm{H} 4$ & 257.9 \\
\hline El Médano 053 & EM 102 & 2 & $\mathrm{H} 4 / 5$ & 82.9 \\
\hline El Médano 054 & EM 061; EM 164 & 16 & $\mathrm{H} 5$ & 385.5 \\
\hline El Médano 060 & EM 109 & 3 & $\mathrm{H} 3$ & 42.1 \\
\hline El Médano 063 & $\begin{array}{l}\text { EM 086; EM 108; EM 152; } \\
\text { EM 158; EM } 167\end{array}$ & 15 & $\mathrm{H} 4$ & 1542.5 \\
\hline El Médano 064 & EM 146 & 2 & $\mathrm{H} 4$ & 32.9 \\
\hline El Médano 066 & EM 071 & 7 & $\mathrm{H} 5$ & 178.8 \\
\hline El Médano 067 & EM 159; EM 163 & 3 & L6 & 53.1 \\
\hline El Médano 074 & EM 143 & 3 & $\mathrm{H} 4$ & 101.4 \\
\hline El Médano 079 & EM 148; EM 149 & 4 & $\mathrm{H} 5$ & 397 \\
\hline El Médano 083 & EM 184 & 2 & $\mathrm{H} 5$ & 487 \\
\hline El Médano 088 & EM 135 & 2 & L6 & 81.1 \\
\hline El Médano 091 & EM 183 & 2 & $\mathrm{H} 5$ & 25 \\
\hline El Médano 099 & EM 126 & 2 & H5 & 594.5 \\
\hline El Médano 103 & EM 133 & 6 & LL6 & 458 \\
\hline El Médano 105 & EM 106; EM 192 & 4 & $\mathrm{H} 5 / 6$ & 123.4 \\
\hline El Médano 125 & EM 150 & 4 & L6 & 149 \\
\hline El Médano 130 & EM 138; EM 142 & 3 & L6 & 82 \\
\hline El Médano 145 & EM 161; EM 190 & 12 & $\mathrm{H} 5$ & 2331.4 \\
\hline
\end{tabular}

${ }^{\text {a }}$ Pairing group names are defined by the first (in numerical order) meteorite belonging to the group.

$\mathrm{EM}=\mathrm{El}$ Médano; $\mathrm{CeC}=$ Caleta $\mathrm{El}$ Cobre .

For ordinary chondrites, we separated H, L, and LL groups: two meteorites from two different groups cannot be paired.

All meteorite duos showing a factor $\mathrm{P}$ higher than 0.9 were then checked "manually" by comparing the textures using a petrographic microscope. Over 10,000 duos, only 200 showed a factor over 0.9 . After manual checking, about a hundred pairings were identified. This may be improved by using additional criteria (such as porosity, polycrystallinity of troilite, and so on), but the manual checking step cannot be avoided to get an accurate pairing. We also checked manually a few dozen duos showing a factor lower than 0.9 (but over 0.8), to check if the limit we fixed was meaningful. None of the duos we examined was found to be paired. The results of our pairing investigation are given in Table 4 . 


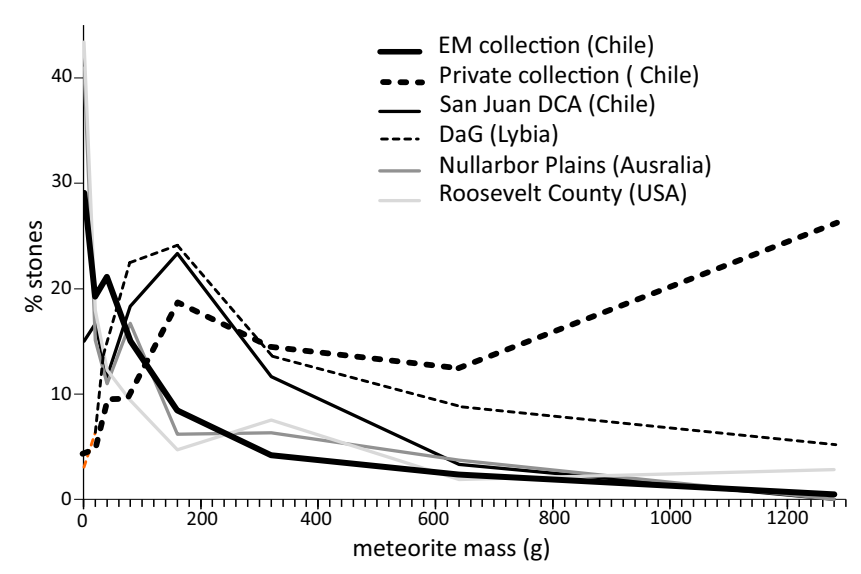

Fig. 4. Distribution of meteorites masses for hot desert meteorites. San Juan data are from Gattacceca et al. (2011), other desert data are from Koblitz (2005). Statistics for El Médano collection meteorites between 0 and $10 \mathrm{~g}$ encompass 22 classified and declared meteorites and 68 unclassified meteorites. Dhofar (Oman), Acfer (Algeria), NWA (Sahara), and Hammadah al Hamra (Libya) have mass distributions similar to Dar al Gani.

\section{STATISTICS OF CHILEAN METEORITE COLLECTIONS}

\section{Mass Distribution}

All 281 meteorites of the EM collection were taken into account. Meteorites masses range from $1.1 \mathrm{~g}$ to $2220 \mathrm{~g}$, with $90 \%$ below $160 \mathrm{~g}$ and $28 \%$ under $10 \mathrm{~g}$ and a median mass of $40 \mathrm{~g}$. The mass distribution (Fig. 4) is broadly similar to that of the Nullarbor Plain, San Juan, and Roosevelt County areas, where systematic searches on foot were performed, with a large population of meteorites having a mass lower than $40 \mathrm{~g}$. Providing that comparable time and attention is spent for searching, it is assumed that all meteorite collections should show a similar percentage of small meteorites. However, the geologic environment is a decisive factor for meteorite recovery: in the San Juan DCA for instance, the high abundance of dark-weathering cmsized terrestrial rocks likely prevented an efficient detection of smaller meteorites (Gattacceca et al. 2011). The intense aeolian erosion evidenced in the San Juan DCA (Gattacceca et al. 2011) would also tend to have small meteorites to disappear faster than in the El Médano and Caleta el Cobre DCAs where aeolian erosion appears to be weaker (ventifacts are more abundant in the San Juan area than in the El Médano and Caleta and Cobre areas).

Meteoroids reaching the Earth are thought to be products from fragmentation in the asteroid belt. Their mass distribution is thus expected to exhibit a powerlaw distribution. From observations of meteors, the

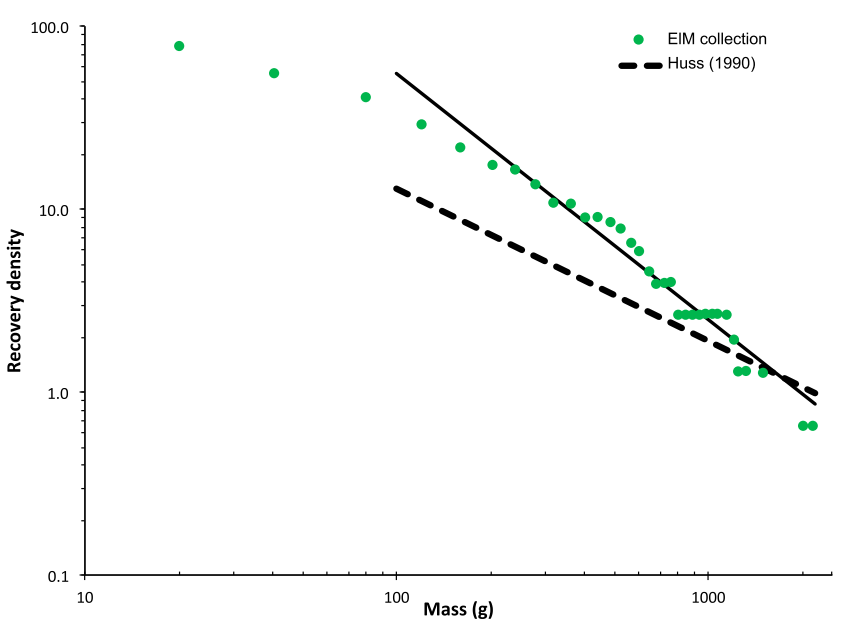

Fig. 5. Cumulative recovery density as a function of mass. Best linear fit is shown $\left(R^{2}=0.9567\right.$ on the range $\left.120-2200 \mathrm{~g}\right)$, and Huss distribution $(\mathrm{s}=-0.83)$ is displayed (dashed line).

slope of the distribution for present-day meteorite falls was calculated to be -0.83 (Huss 1990). We compute here the slope for the mass distribution of the EM Chilean collection for meteorites over $100 \mathrm{~g}$, following the Huss (1990) method. Any difference with the reference slope of -0.83 will be interpreted in terms of processes that have altered the original distribution. Figure 5 presents the data for the EM collection and the regression for masses larger than $100 \mathrm{~g}$. The slope is -1.35 , steeper than the reference distribution also shown on Fig. 5. To test if a simple aeolian erosion could explain this higher slope, we modeled the evolution of the distribution when meteorites are eroded (Fig. 6). To do so, we considered that meteorites are spheres with a density of 3.5 and that aeolian erosion removes a layer of matter of constant thickness all over the sphere. The slope would decrease with increasing aeolian erosion. Thus, aeolian erosion cannot explain the slope we calculate for EM collection. Another explanation would be a higher terrestrial weatheringrelated fragmentation of meteorites in the EM DCA, enabled by an older age of the population. When big meteorites are fragmented, the mass distribution tends toward small masses and the slope increases.

The EM, San Juan DCA, and Nullarbor Plains collections show a lack of meteorites heavier than $1 \mathrm{~kg}$, compared with collection made by car (Dar al Gani and Chilean private collections for instance).

Since the stones were recovered by car, the mass distribution of the private collection shows a totally different pattern than the collection described above. Meteorite masses range from $1.9 \mathrm{~g}$ up to $30.8 \mathrm{~kg}$, with $30 \%$ over $1 \mathrm{~kg}$. Pre-atmospheric mass distribution shows roughly the same pattern as in Dar al Gani DCA for low masses, with an overabundance of stones above 


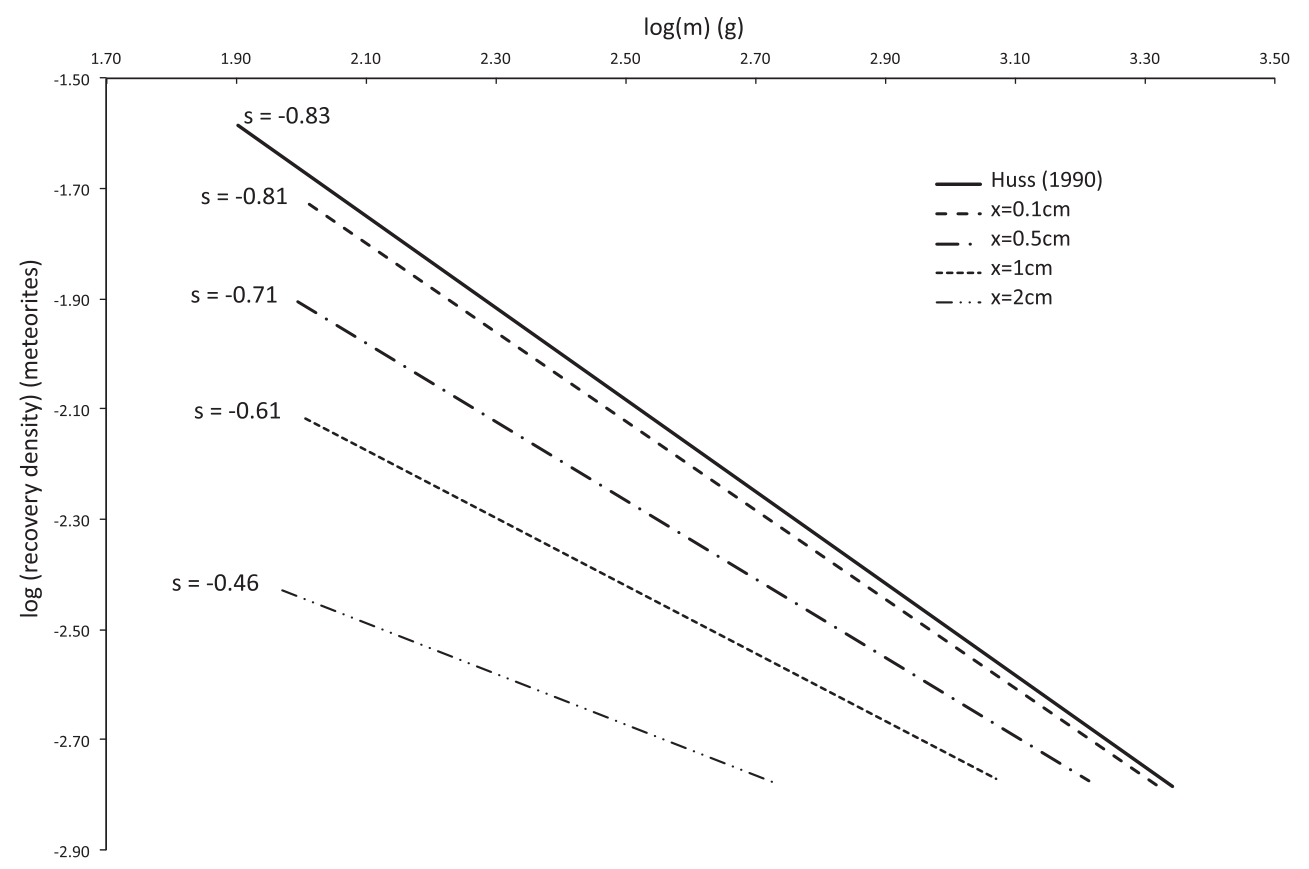

Fig. 6. Results obtained eroding the original distribution proposed by Huss (1990), with x ( $\mathrm{cm}$ ) the thickness of meteorite that has been eroded, considering meteorites as spheres of density 3.5 .

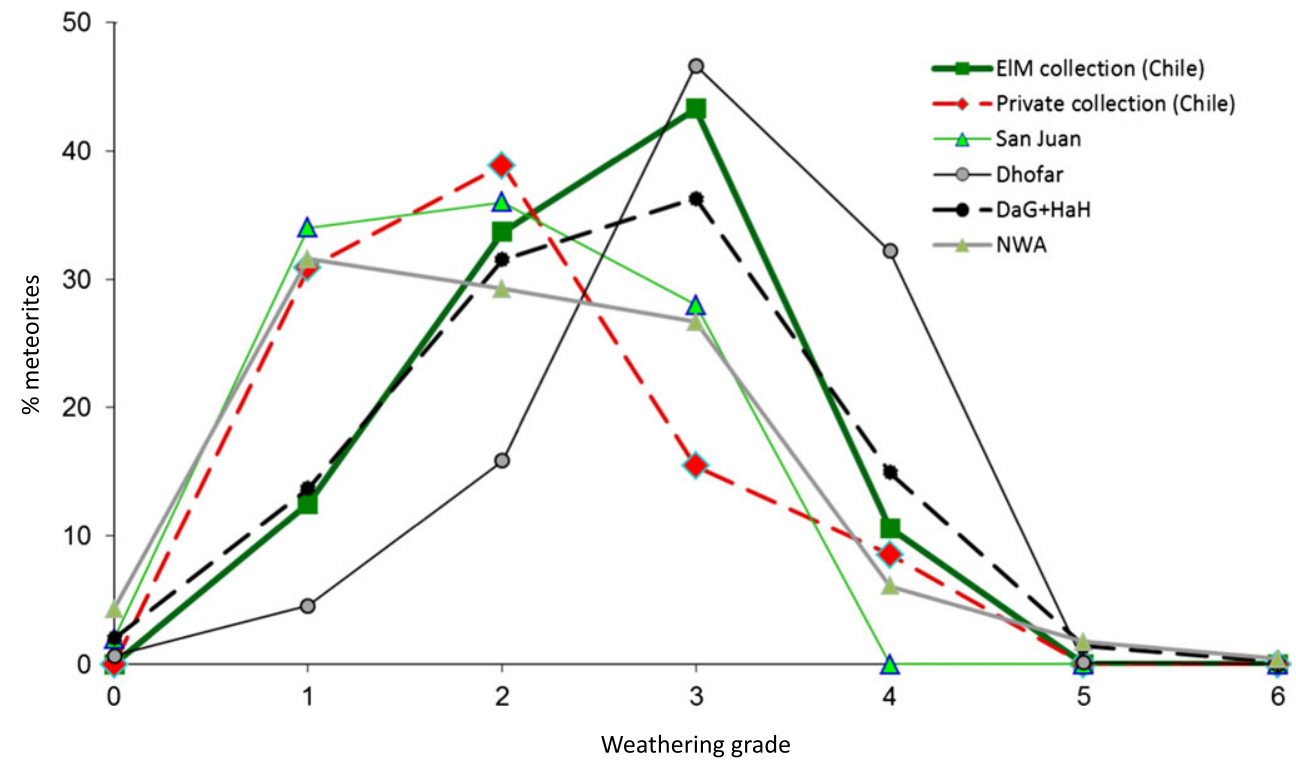

Fig. 7. Distribution of weathering grade for hot deserts meteorites. San Juan data are from Gattacceca et al. (2011), other deserts data are from Koblitz (2005).

$1 \mathrm{~kg}$. The same pattern is found in Dhofar (Oman), Acfer (Algeria), North-West Africa (Sahara), and Hamadah al Hamra (Libya) (Fig. 4).

\section{Weathering Grade}

Compared with the San Juan DCA, as well as with the private Chilean collection, the EM collection shows more weathered meteorites, with 52\% W3 and over and no W0 (Fig. 7). The private collection shows less weathered meteorites, with $70 \%$ below W3. To test the hypothesis that the bigger meteorites get less weathered, we plotted the percentage of meteorites showing a weathering grade higher than W2 for the EM collection before pairing and for the private collection (Fig. 8). In both collections, we note that this percentage decreases 


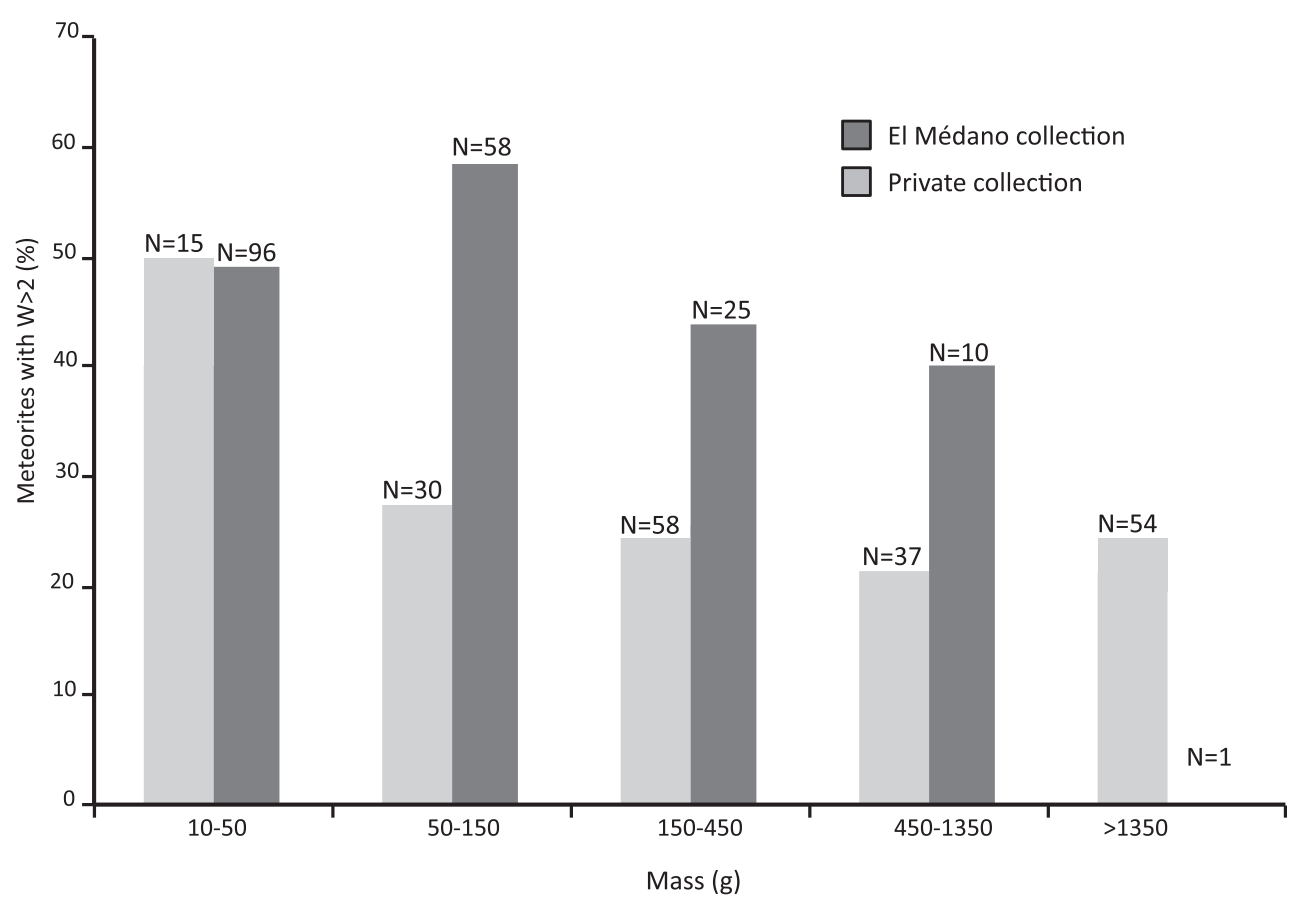

Fig. 8. Percentage of meteorites with a weathering grade higher than W2 for both collections.

with increasing mass, indicating that the larger meteorites are indeed less weathered on average, which is expected considering their smaller surface/volume ratio.

\section{Relative Abundances: Group and Type}

We present the statistical properties of several collections in Table 5: EM and private collections, other hot desert finds (including Dhofar, Acfer, and Dar al Gani collections), Antarctica finds, and falls. The comparison with other collections enables us to consider a possible qualitative change (meaning a change in terms of group and types) in the meteorite flux, if we consider the period of accumulation of the different collections. Antarctica has concentrated meteorites for up to several $100 \mathrm{ka}$ in some places (Huss 1990); terrestrial ages up to $1 \mathrm{Ma}$ have been reported (Nishiizumi et al. 1989). In hot deserts, the age spectrum covers a few dozen kyr (Jull 2006; Hezel et al. 2011). Falls cover the last 200 years.

$\mathrm{H}$ chondrites are overabundant (compared with falls and Antarctica) in the EM collection and the private collection. Pairing in the EM collection lowers the $\mathrm{H} / \mathrm{L}$ ratio (2.13 before pairing, 1.74 after). The $\mathrm{H} / \mathrm{L}$ rations for the EM and private collections, as well as for the San Juan collection (2.00 in Gattacceca et al. 2011), are similar to other hot desert finds (1.44) and significantly higher than the ratio for falls (0.88), suggesting that the present-day composition of the meteorite flux is not representative of the longer term one. A possible explanation for why Antarctica has a relatively low ratio (1.15) is that pairing is impossible because of the transport into ice, with a specific fragmentation process that may affect $\mathrm{H}$ and $\mathrm{L}$ differently.

Although $\mathrm{H} / \mathrm{L}$ ratios are close to each other in the EM collection, private collection, and hot desert finds, the distribution of petrologic types is different: EM and private collections show a higher percentage of $\mathrm{H} 5$ among all $\mathrm{H}$ chondrites ( $46 \%$ and $42 \%$, respectively), while other hot deserts finds show a lower percentage $(33 \%$ H5). An explanation would be that meteorites classified as $\mathrm{H} 5 / 6$ in hot desert collections have been classified as $\mathrm{H} 5$ in our collections: if we add the abundances of $\mathrm{H} 5$ and $\mathrm{H} 5 / 6$ for hot deserts collections, we obtain $44.5 \%$, which is very close to our observations.

L6 chondrites also show a high percentage among all $\mathrm{L}$ chondrites in the EM and private collections $(75 \%$ and $78 \%$, respectively), compared with other hot desert finds (57\% L6). The L6 abundance is reduced to $68.5 \%$ in the private collection after pairing of the only obvious case in this collection, a large L6 shower. The result is still above other hot deserts finds. An explanation is that the composition of the meteorite flux may have changed over time.

We notice in the EM collection a deficit of LL chondrites (abundances of $4.7 \%$ before pairing, 4.9\% after), compared with the fall statistics $(11.0 \%)$. The deficit in the EM collection (already noted in the San Juan DCA on a smaller database; Gattacceca et al. 
Table 5. Relative abundances by groups and types from ElM collection, private collection, falls, Antarctica finds, and hot desert finds.

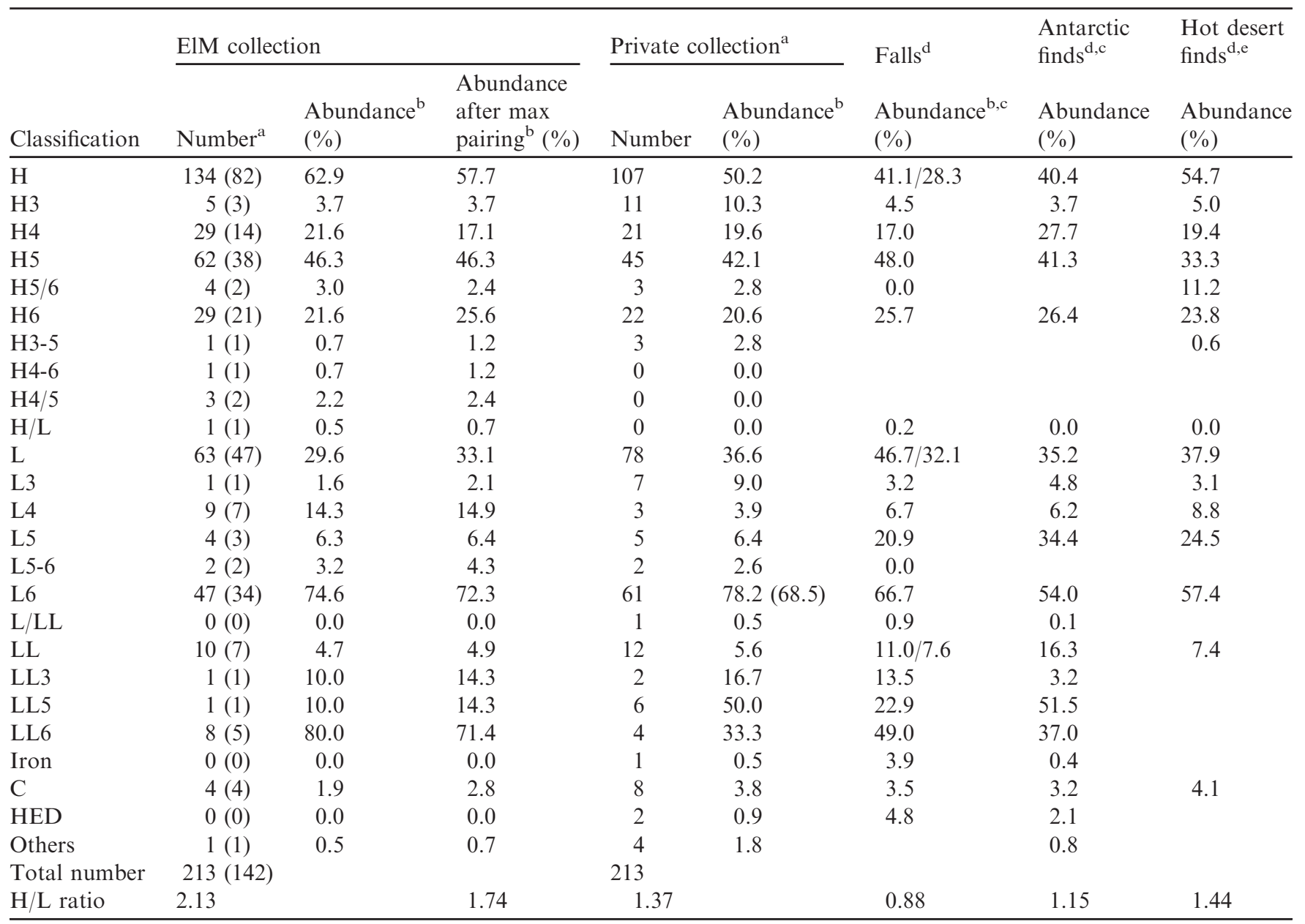

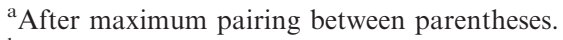

${ }^{b}$ For petrologic types, abundance is within the group.

${ }^{\mathrm{c}}$ Abundance within ordinary chondrites/resp. within total meteorites.

${ }^{\mathrm{d}}$ Data from Meteoritical Bulletin Database (http://www.lpi.usra.edu/meteor/) as of May 2014.

e Includes Dar al Gani, Dhofar, and Acfer collections.
}

2011) can be explained by the fact that LL chondrites contain less FeNi metal than other ordinary chondrites and thus are harder to spot on the field, because of a less brownish color. The private collection shows a smaller deficit $(5.6 \%)$, maybe explained by the fact that LL chondrites have a low magnetic susceptibility and hence were preferentially chosen when the private collection was selected by the private hunters for classification from all the meteorites the three private hunters gathered. As already raised by several authors (Harvey and Cassidy 1989; Benoit and Sears 1996; Gattacceca et al. 2011), another hypothesis is that the flux of meteorites changed qualitatively over the time covered by falls (a few hundred years).

Compared with falls, an overabundance of type 3 ordinary chondrites was observed in the San Juan DCA based on the study of 48 meteorites (Gattacceca et al. 2011). This is not observed anymore for the EM and private collection, both consisting of 213 meteorites. We conclude that the San Juan collection was not large enough to discuss reliably this kind of statistics.

No iron meteorite was found in our systematic search, and only a single one was found in the private collection (Catalina 003, found by the hunter L. Labenne), leading to an abundance on the order of $0.5 \%$. This is at odds with the falls abundances, $3.8 \%$. However, the same deficit of irons is observed in Sahara, Oman, and Antarctica. In deserts experiencing a long human occupation (Sahara, Oman), iron meteorites might have been collected in prehistorical and historical times as a source of iron. In Antarctica, meteorites are transported by ice: high-density iron 
meteorites may have sunk in the ice. For Chilean meteorites, we favor the hypothesis of the deficit being explained by the mass distribution of the various collections. Iron meteorites are indeed usually of large mass, for example, among the 43 irons from Chile only 4 are below $1 \mathrm{~kg}$, with a minimum of $260 \mathrm{~g}$. If we consider the abundance of iron meteorites among the meteorites $>1 \mathrm{~kg}$, we obtain $1.4 \%$ ( 1 over 70 ) for the private collection, and 0 over 3 for the EM collection. On the contrary, iron meteorites seem overabundant in falls, since the mass distribution is biased toward high masses (the median mass being at $1.8 \mathrm{~kg}$ for 1201 samples), due to the higher probability of large falls recovery. It is also possible that the flux changed over time, with a recent increase in the proportion of iron meteorites.

HED meteorites, the most abundant achondrite group apart from iron, yield an abundance of $0 \%$ for the EM collection and $0.9 \%$ for the private collection, again lower than for falls $(4.8 \%)$. We interpret this as due to the difficulty in identifying these rocks in the field (in the absence of fusion crust) because of the presence of abundant terrestrial volcanic rocks of similar color.

To calculate an accurate abundance of carbonaceous chondrites for the EM collection, we need to take into account the fact that the carbonaceous chondrites we classified are all smaller than $10 \mathrm{~g}$. We then calculate the abundance using the total number of meteorites, not only the classified meteorites. We obtain an abundance of $1.4 \%$ before pairing and $1.9 \%$ after pairing, which is low compared with the other collections. Carbonaceous chondrites are also more difficult to spot on the ground, the metal content being lower than in ordinary chondrites. The private collection abundance $(3.8 \%)$ is only slightly higher than that of falls $(3.5 \%)$, maybe because of the bias in classifying unusual stones in this collection.

The abundances distribution is conditioned by several factors: the way of collecting meteorites (by car or by foot), the aspect of the ground (color, sand, or stones), the alteration processes (affecting which type of meteorite will weather faster), and the possible qualitative changes in the flux of meteorites with time.

\section{Meteorite Density}

In this part, only the EM collection is considered, since the private collection does not result from a systematic recovery, making a discussion in terms of density of meteorites impossible. To calculate an accurate meteorite concentration on the ground from the recovery density, we need to correct for two biases. Most of the Atacama arid surface is scattered with dark magmatic rocks or with rocks covered with dark desert varnish (Goldsmith et al. 2013). However, compared with the San Juan area (Gattacceca et al. 2011), the new DCAs reported here are characterized by a rather light cream-colored main lithology (upper Cretaceous acid volcanic or intrusive rocks) with little amount of darker material. Meteorites were identified in the field mostly by their brownish color, due to weathering of metal or sulfides, although a few fresh fusion-crusted and blackcolored meteorites were found. Therefore, meteorites with low metal or sulfide content are more difficult to spot. HED meteorites, Martian and lunar meteorites, and aubrites (amounting to about $8 \%$ of meteorites based on fall statistics) have a metal plus sulfide content one order of magnitude lower than LL chondrites (e.g., Rochette et al. 2003, 2009), and as such are almost unrecognizable in the field if they do not possess the remains of a fusion crust. To take into account this bias, we increase the number of meteorites by $8 \%$.

Although search on foot allows a better recovery of meteorites, the recovery efficiency is not perfect. We walked in line spaced by $10 \mathrm{~m}$ and if we plot the number of meteorites found against the distance to the walking line, we notice that there is a deficit of meteorites found in the $2-5 \mathrm{~m}$ range, with $68 \%$ found within $2 \mathrm{~m}$ of the hunter. Following the same reasoning as in Gattacceca et al. (2011), we calculate that about $69 \%$ of the meteorites located between $2 \mathrm{~m}$ and $5 \mathrm{~m}$ away from the walking grid was not collected. A solution would be to reduce the walking distance to about $4 \mathrm{~m}$ instead of $10 \mathrm{~m}$, but the trade-off is that we wanted to cover a significant surface to get reliable statistics.

With 191 meteorites (not considering the 22 unusual stones under $10 \mathrm{~g}$ ) heavier than $10 \mathrm{~g}$ collected on $1.5 \mathrm{~km}^{2}$, the recovery density is 127 meteorites above $10 \mathrm{~g} \mathrm{~km}^{-2}$ (after pairing 86 meteorites $>10 \mathrm{~g} \mathrm{~km}^{-2}$ ). Taking into account the two biases described above, we obtain a real meteorite density of 225 (respectively, 152) meteorites above $10 \mathrm{~g} \mathrm{~km}^{-2}$ before (respectively, after) pairing. This is by far the densest meteorite collection area ever described, even compared to Antarctica. A few hypotheses can be considered to explain such a high concentration of meteorites.

Individual search areas are rather small (less than one twentieth of $\mathrm{km}^{2}$ ) compared with strewn fields of a given fall (up to a few dozen $\mathrm{km}^{2}$; Gnos et al. 2009). As explained in Halliday et al. (1989), each area could show more falls than are representative of the surface itself. Following this reasoning, the concentration would be slightly overestimated, though quantification of this overestimate is difficult.

In contrast to the situation in Antarctica, there are no obvious concentration mechanisms, although some meteorites may have crept slowly down the slopes, as 
the quartz pebbles may have done (see the Geology and Geomorphology section). We indeed observe that fragments of the same meteorite are very often dispersed along the slope, with smaller fragments downslope. During such long-term creeping, concentration could occur on lower slope areas.

Assuming Halliday et al. (1989) modeled an accurate flux ( 83 meteorites above $10 \mathrm{~g}$ per million $\mathrm{km}^{2}$ per year), the observed concentration (between 152 and 225 meteorites $>10$ g. $\mathrm{km}^{-2}$ ) would indicate a meteorite accumulation over about $2 \mathrm{Myr}$ at El Médano. This is a surprisingly long duration for hot deserts, although meteorites may have indeed accumulated for such a long time, according to the old surface age and longstanding hyperaridity in this area (Dunai et al. 2005). It is also possible that Halliday's model is inaccurate for low masses. Measurements of the cosmogenic nuclides content of the meteorites are in progress to eventually obtain a terrestrial age distribution for the EM collection. Also, even if the correlation is not clearly established yet, the high weathering grade of the EM collection compared to, for example, the San Juan collection, is a hint toward older ages.

\section{CONCLUSIONS}

We classified 213 meteorites, including 191 meteorites larger than $10 \mathrm{~g}$, recovered by systematic search on foot over a surface of $1.5 \mathrm{~km}^{2}$ in El Médano and Caleta el Cobre DCAs ("El Médano collection"). After maximum pairing, this corresponds to 142 different falls. We completed this systematic collection with 213 other meteorites recovered by private hunters in several Chilean DCAs in the Central Depression of the Atacama Desert (private collection).

The El Médano collection shows a mass distribution typical of areas searched on foot (high abundance of small masses, median mass $40 \mathrm{~g}$ ), whereas the private collection is typical of areas searched by car (overabundance of meteorites above $1 \mathrm{~kg}$ ).

The El Médano collection shows weathered meteorites, with $52 \%$ over $\mathrm{W} 2$, whereas the private collection has better preserved meteorites $(70 \%$ of $\mathrm{W} 2$ or lower). Both collections show a correlation between mass and weathering, the larger stones being generally less weathered.

We notice an overabundance of $\mathrm{H}$ chondrites compared with $\mathrm{L}$ chondrites in both collections with respect to the falls statistics, in line with results from other hot and cold deserts. We feel that the case for a large change of $\mathrm{H} / \mathrm{L}$ ratio over time is more and more robust.

The Central Depression of Atacama was already shown to be an exceptional field for recovery of meteorites (Gattacceca et al. 2011), and the results of the present study show an exceptional meteorite concentration comprised between 152 and 225 meteorites over $10 \mathrm{~g}$ per $\mathrm{km}^{2}$. Although these numbers should be slightly reduced by the effect of the size of the search areas compared to the size of a typical strewn field, we expect the meteorites to have accumulated over a long time span of several hundreds kyr. An old age of the population is also supported by the frequent observed fragmentation of the meteorites and their rather strong weathering with $52 \%$ over W2. The Atacama Desert has been hyperarid for several Myr and the El Médano and Caleta el Cobre DCAs experienced a negligible denudation rate, which allows the meteorites to be preserved over a long time span. In addition, the lack of human occupation also allowed their preservation over a longer time period in this desert comparatively to the Sahara and Arabia deserts.

Acknowledgments-M. Arnold, G. Aumaître, and K. Keddadouche are thanked for the ${ }^{10} \mathrm{Be}$ measurements at the ASTER AMS national facility (CEREGE, Aix-enProvence, France), which is supported by the INSU/ CNRS, the ANR through the "Projets thématiques d'excellence" program for the "Equipements d'excellence" ASTER-CEREGE action, IRD and CEA. The ASTER GDEM data product was obtained through the online Data Pool at the NASA Land Processes Distributed Active Archive Center (LP DAAC), USGS/Earth Resources Observation and Science (EROS) Center, Sioux Falls, South Dakota (https://lpdaac.usgs.gov/data_access). D. Gaetano is thanked for proofreading the language. Financial support was provided by INSU and CNES through the Programme National de Planétologie.

Editorial Handling-Dr. Michael Zolensky

\section{REFERENCES}

Al-Kathiri A., Hofmann B. A., Jull A. J. T., and Gnos E. 2005. Weathering of meteorites from Oman: Correlation of chemical and mineralogical weathering proxies with $14 \mathrm{C}$ terrestrial ages and the influence of soil chemistry. Meteoritics \& Planetary Science 40:1215-1240.

Arnold M., Merchel S., Bourlès D. L., Braucher R., Benedetti L., Finkel R. C., Aumaitre G., Gottdang A., and Klein M. 2010. The French accelerator mass spectrometry facility ASTER: Improved performance and developments. Nuclear Instruments and Methods in Physics Research B 268:1954-1959.

Benoit P. H. and Sears D. W. G. 1996. Rapid changes in the nature of the $\mathrm{H}$ chondrites falling to Earth. Meteoritics \& Planetary Science 31:81-86.

Benoit P. H., Sears H., and Sears D. W. G. 1993. The natural thermoluminescence of meteorites: 5. Ordinary chondrites 
at the Allan Hills Ice Fields. Journal of Geophysical Research 98:1875.

Benoit P. H., Roth J., Sears H., and Sears D. W. G. 1994. The natural thermoluminescence of meteorites: 7. Ordinary chondrites from the Elephant Moraine region, Antarctica. Journal of Geophysical Research 99(E1):2073-2085. doi:10.1029/93JE02474.

Benoit P. H., Sears D. W. G., Akridge J. M. C., Bland P. A., Berry P. A., and Pillinger C. T. 2000. The non-trivial problem of meteorite pairing. Meteoritics \& Planetary Science 35:393-417.

Brown E. T., Edmond J. M., Raisbeck G. M., Yiou F., Kurz M. D., and Brook E. J. 1991. Examination of surface exposure ages of Antarctic moraines using in situ produced ${ }^{10} \mathrm{Be}$ and ${ }^{26} \mathrm{Al}$. Geochimica et Cosmochimica Acta 55:2269-2283.

Chmeleff J., von Blanckenburg F., Kossert K., and Jakob J. 2010. Determination of the ${ }^{10} \mathrm{Be}$ half-life by multicollector ICP-MS and liquid scintillation counting. Nuclear Instruments and Methods in Physics Research B 268:192-199.

Clarke J. D. A. 2006. Antiquity of aridity in the Chilean Atacama Desert. Geomorphology 73:101-114.

Dunai T. J., Gonzalez Lopez G. A., and Juez-Larré J. 2005. Oligocene-Miocene age of aridity in the Atacama Desert revealed by exposure dating of erosion-sensitive landforms. Geology 33:321-324.

Gattacceca J., Eisenlohr P., and Rochette P. 2004. Calibration of in situ magnetic susceptibility measurements. Geophysical Journal International 158:42-49.

Gattacceca J., Valenzuela M., Uehara M., Jull A. J. T., Giscard M., Rochette P., Braucher R., Suavet C., Gounelle M., Morata D., Munayco P., Bourot-Denise M., Bourles D., and Demory F. 2011. The densest meteorite collection area in hot deserts: The San Juan meteorite field (Atacama Desert, Chile). Meteoritics \& Planetary Science 46:1276-1287.

Gnos E., Lorenzetti S., Eugster O., Jull A. J. T., Hofmann B. A., Al-Kathiri A., and Eggimann M. 2009. The Jiddat al Harasis 073 strewn field, Sultanate of Oman. Meteoritics \& Planetary Science 44:375-387.

Goldsmith Y., Stein M., and Enzel Y. 2013. From dust to varnish: Geochemical constraints on rock varnish formation in the Negev Desert, Israel. Geochimica et Cosmochimica Acta 126:97-111.

Halliday I., Blackwell A. T., and Griffin A. A. 1989. The flux of meteorites on the Earth's surface. Meteoritics 24:173-178.

Harvey R. P. and Cassidy W. A. 1989. A statistical comparison of Antarctic finds and modern falls: Mass frequency distributions and relative abundance by type. Meteoritics 14:9-14.

Hezel D. C., Schlüter J., Kallweit H., Jull A. J. T., Al Fakeer O. Y., Al Shamsi M., and Strekopytov S. 2011. Meteorites from the United Arab Emirates: Description, weathering, and terrestrial ages. Meteoritics \& Planetary Science 46:327-336.

Huss G. R. 1990. Meteorite infall as a function of mass: Implications for the accumulation of meteorites on Antarctic ice. Meteoritics \& Planetary Science 25:41-56.

Jull A. J. T. 2006. Terrestrial ages of meteorites. Meteorites and the Early Solar System II:889-905.

Koblitz J. 2005. MetBase-Meteorite data retrieval software, version 7.1. Bremen, Germany: Koblitz. CD-ROM.
Korschinek G., Bergmaier A., Faestermann T., Gerstmann U. C., Knie K., Rugel G., Wallner A., Dillmann I., Dollinger G., von Gostomski Ch. L., Kossert K., Maitia M., Poutivtsev M., and Remmert A. 2010. A new value for the half-life of ${ }^{10} \mathrm{Be}$ by heavy-Ion elastic recoil detection and liquid scintillation counting. Nuclear Instruments and Methods in Physics Research B 268:187-191.

Merchel S. and Herpers U. 1999. An update on radiochemical separation techniques for the determination of long-lived radionuclides via accelerator mass spectrometry. Radiochimica Acta 84:215-219.

Merchel S., Arnold M., Aumaître G., Benedetti L., Bourlès D. L., Braucher R., Alfimov V., Freeman S. P. H. T., Steier P., and Wallner A. 2008. Towards more precise ${ }^{10} \mathrm{Be}$ and ${ }^{36} \mathrm{Cl}$ data from measurements at the $10-14$ level: Influence of sample preparation. Nuclear Instruments and Methods in Physics Research B 266:4921-4926.

Munoz C., Guerra N., Martinez-Fris J., Lunar C., and Cerda J. 2007. The Atacama Desert: A preferential arid region for the recovery of meteorites-Find location features and strewfield distribution patterns. Journal of Arid Environments 71:188-200.

Nishiizumi K., Elmore D., and Kubik P. W. 1989. Update on terrestrial ages of Antarctic meteorites. Earth and Planetary Science Letters 93:299-313.

Rochette P., Sagnotti L., Bourot-Denise M., Consolmagno G., Folco L., Gattacceca J., Osete M. L., and Pesonen L. 2003. Magnetic classification of stony meteorites: 1. Ordinary chondrites. Meteoritics \& Planetary Sciences 38:251-258.

Rochette P., Gattacceca J., Bourot-Denise M., Consolmagno G., Folco L., Kohout T., Pesonen L., and Sagnotti L. 2009. Magnetic classification of stony meteorites: 3. Achondrites. Meteoritics \& Planetary Science 44:405-427.

Russel S., Zolensky M., Righter K., Folco L., Jones R., Connolly H. C. Jr., Grady M., and Grossman J. N. 2005. The Meteoritical Bulletin, No. 89. Meteoritics \& Planetary Science 40:A201-A263.

Ruzicka A., Grossman J. N., and Garvie L. 2014. Meteoritical Bulletin, No. 100. Meteoritics \& Planetary Science 49:E1E101.

Ruzicka A., Grossman J., Bouvier A., Herd C. D. K., and Agee C. B. 2015a. The Meteoritical Bulletin, No. 101. Meteoritics \& Planetary Science 50:1661. doi:10.1111/ maps. 12490.

Ruzicka A., Grossman J., Bouvier A., Herd C. D. K., and Agee C. B. 2015b. The Meteoritical Bulletin, No. 102. Meteoritics \& Planetary Science 50:1662. doi:10.1111/ maps. 12491.

Schlüter J., Schultz L., Thiedig F., Al-Mahdi B. O., and Abu Aghreb A. E. 2002. The Dar al Gani meteorite field (Libyan Sahara): Geological setting, pairing of meteorites, and recovery density. Meteoritics \& Planetary Science 37:1079-1093.

Stone J. O. 2000. Air pressure and cosmogenic isotope production. Journal of Geophysical Research 105:23,75323,759 .

Van Schmus W. R. and Wood J. A. 1967. A chemical petrologic classification for the chondritic meteorites. Geochimica et Cosmochimica Acta 81:747-765.

Wlotzka F. 1993. A weathering scale for the ordinary chondrites (abstract). Meteoritics 28:460. 